\title{
A prospective study of chlamydial, mycoplasmal, and viral infections in a neonatal intensive care unit
}

\author{
P T RUDD AND D CARRINGTON \\ Departments of Paediatrics and Neonatal Medicine and Virology, Hammersmith Hospital and Royal \\ Postgraduate Medical School, London
}

SUMMARY In a prospective study of non-bacterial infection in a neonatal intensive care unit in north west London, Chlamydia trachomatis infection was identified in 4 of 280 babies $(1.4 \%)$ and was the most common cause of neonatal ophthalmia. One of the four developed pneumonitis. Ureaplasma urealyticum was found to colonise the nasopharynx in 53 of 235 babies $(22 \cdot 6 \%)$, with Mycoplasma hominis present in 6 of 235 babies $(2.6 \%)$. There was a statistically significant association between $U$ urealyticum colonisation and preterm birth or prolonged rupture of membranes. Colonisation occurred more commonly in babies with apnoea.

Viral infection was detected in 16 of 280 babies (5.7\%). Rotavirus was identified in 5 of 170 babies $(2 \cdot 9 \%)$ and was associated with necrotising enterocolitis in two infants and with bloody diarrhoea in another. Respiratory syncytial virus, which was identified in 4 of 280 babies $(1.4 \%)$, was not associated with lower respiratory tract infection.

Chlamydia trachomatis and the mycoplasmas, Ureaplasma urealyticum (ureaplasmas) and Mycoplasma hominis, are acquired sexually and transmitted from the genital tract of the mother to her infant. $C$ trachomatis is a cause of neonatal ophthalmia and pneumonitis which, although self-limiting, is a notable cause of hospital admission in American infants with respiratory infections. ${ }^{1}$ Although chlamydial infection may occur in 1 to $2 \%$ of newborn term infants in the United States, ${ }^{2-4}$ the few prospective studies carried out in England have shown a lower rate of infection. Watson and Gairdner ${ }^{5}$ detected chlamydia ophthalmia in 4 of 2700 babies delivered in the maternity hospital in Cambridge. More recently, this condition was seen in only 1 of 450 consecutive births in Southampton. ${ }^{6} C$ trachomatis was not isolated from the cervix of 107 patients attending an antenatal clinic in north west London. ${ }^{7}$ Recent national increases in the incidence of sexually transmitted disease and the probability that these were relevant to our area led us to suspect that $C$ trachomatis was an important cause of neonatal conjunctivitis in our population.

Isolation of $U$ urealyticum from the genital tract during preterm labour has been shown to be associated with chorioamnionitis. ${ }^{8}$ Isolation is directly related to preterm labour as well as to prolonged rupture of membranes. ${ }^{9}$ While there is little information regarding the effect of ureaplasmas on the preterm neonate, Stagno et al ${ }^{10}$ isolated $U$ urealyticum from a number of infants admitted to hospital with pneumonitis in Birmingham, Alabama. $M$ hominis, which is transmitted less commonly to the newborn, ${ }^{9}$ has been isolated from infants with meningitis ${ }^{11}$ and cerebral abscess. ${ }^{12}$

Neonatal viral infection may present very differently from infection in later life. ${ }^{13-15}$ While rotavirus infection has been reported to cause mild or asymptomatic infection in the newborn, ${ }^{16} 17$ a recent report suggests an association with more severe gastroenteritis, including necrotising enterocolitis. ${ }^{18}$

We aimed to establish the incidence of chlamydial, mycoplasmal, and viral infections among infants on the neonatal unit, and to assess the contribution of $U$ urealyticum and $C$ trachomatis to respiratory disease in the preterm infant.

\section{Patients and methods}

This research project was approved by the hospital ethical committee and informed consent was obtained from parents. All babies admitted to the neonatal intensive care unit between late August 1981 and December 1982 were eligible for the study. Of these 355 babies, 75 were excluded because they 
Table 1 Characteristics of patients

\begin{tabular}{|c|c|}
\hline Number of patitents & 280 \\
\hline Median gestation (weeks) & 32 \\
\hline Median birthweight $(\mathrm{g})$ & 1620 \\
\hline Gestation groups & $n$ \\
\hline $25-28$ weeks & 53 \\
\hline 29-32 weeks & 110 \\
\hline 33-36 weeks & 82 \\
\hline $37-42$ weeks & 35 \\
\hline \multicolumn{2}{|l|}{ Socioeconomic groups } \\
\hline I & 32 \\
\hline II & 34 \\
\hline III & 19 \\
\hline IV & 73 \\
\hline V & 34 \\
\hline Unsupported mother & 26 \\
\hline Unemployed father & 19 \\
\hline Not known & 43 \\
\hline \multicolumn{2}{|l|}{ Race } \\
\hline Caucasian & 179 \\
\hline Asian & 62 \\
\hline Negro & 33 \\
\hline Mixed & 6 \\
\hline \multicolumn{2}{|l|}{ Clinical features } \\
\hline Idiopathic respiratory distress syndrome & 82 \\
\hline Oxygen for more than 5 days & 115 \\
\hline Apnoea & 39 \\
\hline Necrotising enterocolitis & $9^{*}$ \\
\hline Purulent conjunctivitis & 14 \\
\hline Prolonged rupture of membranes & 54 \\
\hline
\end{tabular}

* Eight cases of necrotising enterocolitis during period of stool collection.

either died $(n=35)$ or left the neonatal intensive care unit $(n=40)$ before specimens could be taken. The characteristics of the 280 infants studied are given in Table 1.

Clinical details were recorded on a pro forma and transferred to a computer at the end of the study. Prolonged rupture of membranes was defined as membranes ruptured for more than 24 hours before delivery. Criteria for idiopathic respiratory distress syndrome were two of the following signs after four hours: respiratory rate greater than $60 /$ minute, intercostal recession, and grunting. Apnoea was defined as three or more episodes of duration 10 seconds or longer, associated with brachycardia (pulse less than 100/minute) or cyanosis in a 24 hour period. Any baby with a purulent exudate and inflammation of the conjunctiva was said to have conjunctivitis. The criteria for a diagnosis of necrotising enterocolitis were bloody diarrhoea, abdominal distension, and pneumatosis intestinalis on radiographs. Gestational age was estimated using maternal history, ultrasound, and Dubowitz assessment. ${ }^{19}$ Logistic regression analysis was used to determine the effects of certain variables on $U$ urealyticum colonisation and $\chi^{2}$ tests were used to observe differences between social and racial groups.
Nasopharyngeal aspirates, conjunctival swabs, stools, and urine specimens were collected at weekly intervals from the babies. Nasopharyngeal aspirates were collected using a size 5 feeding tube connected to a sputum trap, to which $50 \mathrm{~mm} \mathrm{Hg}$ suction was applied. The conjunctival specimens collected at the same time were obtained by pulling a cottonwool tipped plastic swab across the everted lower eyelid of one eye. Both specimens were separately immersed in $0.2 \mathrm{M}$ sucrose phosphate before the immediate inoculation into mycoplasma growth medium and transport to the laboratory in wet ice. Where clinically indicated, cerebrospinal fluid was examined. The nasopharyngeal aspirates and conjunctival specimens were collected over 16 months for chlamydial and viral isolation. $U$ realyticum and $M$ hominis cultures were begun in November 1981, two months after the study began, so that only 235 of the 280 babies studied were screened. Stools and urine were collected for a 12 month period only, to include 209 of the 280 babies.

\section{Laboratory methods}

The mycoplasma medium was inoculated at the time of collection; slides were prepared for respiratory syncytial virus immunofluorescence on the day of collection, and the test was completed in batches later. For the first half of the study the nasopharyngeal aspirates and conjunctival swabs were frozen at $-70^{\circ} \mathrm{C}$ before $C$ trachomatis and virus isolation; during the second half these were inoculated on the same day. Isolation was performed as follows:

C trachomatis. Aliquots $(1 \mathrm{ml})$ of McCoy cells $(4 \times$ $10^{5}$ cells) in growth medium (Minimal Essential Medium-Gibco MEM with $10 \%$ fetal bovine serum-Flow Laboratories) were pipetted into plastic, flat bottomed tubes (Redhill Surgical, E 5/R), each containing a $13 \mathrm{~mm}$ glass cover slip (Slaughter Ltd, No. 3). ${ }^{20}$ These were incubated at $37^{\circ} \mathrm{C}$ for 24 hours, by which time a monolayer had formed. They were then inoculated with the clinical specimens and underwent centrifugation at $3000 \mathrm{~g}$ at $35^{\circ} \mathrm{C}$ in an MSE Mistral 6L for one hour. The medium was then replaced with $1 \mathrm{ml}$ aliquots of maintenance medium (Gibco MEM with 5\% fetal bovine serum). Cultures were then incubated at $37^{\circ} \mathrm{C}$ for 72 hours. Specimens were fixed with $100 \%$ methanol and stained with buffered Giemsa pH 6.8. ${ }^{21}$ Cover slips were dried and mounted on microscope slides before examination under darkground illumination using an Olympus microscope. Chlamydial inclusion bodies showed bright green against the dull, dark purple cell monolayer. Control specimens were set up with 
each batch. The effect of freezing on inclusion counts was studied on control specimens and was found to be negligible when stored at $-70^{\circ} \mathrm{C}$ in $0.2 \mathrm{M}$ sucrose phosphate.

Mycoplasmas. Isolation in broth and in agar was undertaken. Selective medium containing urea $(1 \%)$ in broth at $\mathrm{pH} 6.3$ for $U$ urealyticum ${ }^{22}$ and arginine (1\%) broth at $\mathrm{pH} 6.7$ for $M$ hominis was used (Oxoid formulations). Lincomycin $(15 \mu \mathrm{g} / \mathrm{ml})$ was added to urea broth, but because of the high rate of bacterial contamination of cultures, vancomycin $\mathrm{HC} 1(5 \mu \mathrm{g} / \mathrm{ml})$ was added to both types for the last 6 months of the study because it was found to reduce bacterial contamination without inhibiting mycoplasmal growth. Clinical specimens were inoculated into urea and arginine broth in screw capped glass bijou bottles as well as on agar. The specimens were incubated at $37^{\circ} \mathrm{C}$, and agar plates were incubated in a $\mathrm{CO}_{2}-\mathrm{H}_{2}$ (Becton Dickinson) anaerobic jar. The broths were observed daily, and agar plates were examined under the low power of a microscope on alternate days. Cultures were discarded after 7 days if negative.

In the presence of $U$ urealyticum the urea broth turned from yellow to magenta; a similar colour change was seen with $M$ hominis in arginine broth. Identification was confirmed by the presence of characteristic dark staining $U$ urealyticum colonies on agar after either primary isolation or subculture; $M$ hominis gave the typical 'fried egg' appearance and showed growth inhibition in the presence of paper discs impregnated with $M$ hominis antiserum.

\section{Virus isolation}

Nasopharyngeal aspirates, urine, stool, and cerebrospinal fluid specimens were inoculated into monolayers of human fetal lung fibroblasts and kidney cells, cynomologous monkey kidney cells, and Hep 2 cells, as appropriate. Cell lines were propagated in Medium 199 (Gibco) with 10\% fetal bovine serum and maintained in Medium 199 with $1 \%$ fetal bovine serum. Stools were homogenised in phosphate buffered saline; the supernatant was divided and one aliquot was frozen at $-70^{\circ} \mathrm{C}$ for use in the rotavirus enzyme linked immunosorbent assay (ELISA) and electron microscopy studies. The rest was treated with chloroform, and the supernatant was inoculated on the cell monolayer. Urine was stored in an equal volume of $70 \%$ sorbitol before inoculation on fibroblast cells. After a one hour period of adsorption the medium was changed. The tubes were rolled at $33^{\circ} \mathrm{C}$ and $37^{\circ} \mathrm{C}$ according to cell type and examined every three days for evidence of viral cytopathic effect. On the 10th day kidney cultures were haemadsorbed with human ' $\mathrm{O}$ ' red blood cells. Urine cultures were observed for 28 days and other cultures for 21 days. Identification of isolates was carried out using neutralisation tests in compatible cell lines using standard antiviral antisera raised in animals.

Respiratory syncytial virus immunofluorescence. Slides with $2 \times 5 \mathrm{~mm}$ spots of epithelial cells from the nasopharyngeal aspirates were prepared using a cytospin technique (Shandon). After fixation in acetone and storage at $-20^{\circ} \mathrm{C}$, an indirect immunofluorescence technique was used, ${ }^{23}$ taking care to incorporate adequate controls. Slides were examined with a Leitz UV microscope.

Rotavirus ELISA. The Rotazyme system (Abbott Laboratories) was used according to the manufacturer's recommendations. Positive samples were confirmed by electron microscopy using the negative stain phosphotungstic acid, $\mathrm{pH} 6 \cdot 8$.

Rubella serology. Selected sera was examined by the haemagglutination inhibition test for rubella antibodies in serum and, if more than $24 \mathrm{IU} / \mathrm{ml}$, rubella specific IgM studies were performed after physical separation of the IgM by sucrose density fractionation.

\section{Results}

A summary of all isolations is given in Table 2 . $C$ trachomatis was identified in 4 of 280 babies

Table 2 Agents identified from the different specimens

\begin{tabular}{|c|c|c|c|}
\hline Agent & $\begin{array}{l}\text { No of } \\
\text { babies } \\
\text { screened }\end{array}$ & $\begin{array}{l}\text { No of } \\
\text { babies } \\
\text { infected }\end{array}$ & $\begin{array}{l}\text { Nature of specimen } \\
\text { positive }\end{array}$ \\
\hline $\begin{array}{l}\text { Chlamydia } \\
\text { trachomatis }\end{array}$ & 280 & 4 & $\begin{array}{l}\text { Conjunctival swab-3 } \\
\text { (NPA positive in } \\
\text { 1/3) C trachomatis } \\
\text { specific IgM positive } \\
\text { in fourth baby } \\
\text { (serum) }\end{array}$ \\
\hline $\begin{array}{l}\text { Mycoplasma } \\
\text { hominis } \\
\text { Ureaplasma }\end{array}$ & 235 & 6 & NPA \\
\hline urealyticum & 235 & 53 & NPA \\
\hline Rotavirus & 170 & 5 & Stool \\
\hline Coxsackie B2 & 280 & 2 & NPA \\
\hline Cytomegalovirus & 280 & 2 & $\begin{array}{l}\text { NPA } \\
\text { Urine }\end{array}$ \\
\hline $\begin{array}{l}\text { Respiratory } \\
\text { syncytial virus }\end{array}$ & 280 & 4 & NPA \\
\hline Parainfluenza 1 & 280 & 1 & NPA \\
\hline Parainfluenza 3 & 280 & 1 & NPA \\
\hline Rubella & 280 & 1 & $\begin{array}{l}\text { Serum. Rubella } \\
\text { specific IgM }\end{array}$ \\
\hline
\end{tabular}


$(1 \cdot 4 \%)$. The agent was isolated from the conjunctivae of three babies with neonatal ophthalmia; identification was confirmed by serology in a fourth baby who developed pneumonitis after treatment of an early eye infection with topical sulphacetamide alone. $C$ trachomatis specific IgM in serum was detected in this case by the microimmunofluorescence test. $C$ trachomatis was isolated from a nasopharyngeal aspirate in one of the babies with conjunctivitis but with no evidence of pneumonitis. Pneumonitis may have been prevented by the prompt use of systemic erythromycin in three infected babies. Bacterial infection accounted for only three of the 14 cases of conjunctivitis during the study. In 7 no agent was isolated.

$M$ hominis was isolated from the nasopharyngeal aspirates in 6 of 235 babies $(2.6 \%)$; in four of these there had been prolonged rupture of membranes, and two of the mothers had clinical signs of amnionitis. One baby had persistent pneumonia after operation for tracheo-oesophageal fistula. In another, prolonged oxygen dependence followed idiopathic respiratory distress syndrome and Haemophilus influenzae septicaemia. U urealyticum was isolated from 53 of 235 infants $(22 \cdot 6 \%)$. Specimens were taken from some of their mothers in a separate study, (Lamont R, Taylor Robinson D. Personal communication 1983) and it seemed that $40 \%$ of colonised mothers transmitted this organism to their infants. Certain factors were considered in relation to colonisation, and they are given in Table 3 . The relation between gestation, prolonged rupture of membranes, and colonisation reached statistical significance. Thirteen of 29 babies with apnoea were colonised, but this did not reach significance.

Evidence of viral infection was found in $5.7 \%$ of infants. Rotavirus was identified in 5 of 170 babies $(2.9 \%)$; in two of these on more than one occasion. In 8 of the 170 babies who developed necrotising enterocolitis, two excreted rotavirus in faeces; one of them after the signs of illness had appeared. Another baby developed bloody diarrhoea, while a further two had subclinical infections.

Table 3 Factors considered in relation to $U$ urealyticum isolation $(n=235)$

\begin{tabular}{ll}
\hline & $P$ value \\
\hline Gestation & $0 \cdot 01$ \\
Prolonged rupture of membranes & $<0 \cdot 01^{*}$ \\
Apnoea & $0 \cdot\left(06^{*}\right.$ \\
Idiopathic respiratory distress syndrome & $0 \cdot 3^{*}$ \\
Oxygen for more than 5 days & $0 \cdot 3^{*}$ \\
Social class & $\mathrm{NS}$ \\
Racial group & $\mathrm{NS}$ \\
\hline
\end{tabular}

* Logistic regression analysis (a form of multiple regression) used to eliminate the effect of gestation on colonisation from the calculation
Respiratory syncytial virus was identified in 4 of 280 babies $(1 \cdot 4 \%)$. In three, excessive mucoid secretions from the respiratory tract were observed, but no evidence of pneumonitis or bronchiolitis was found. Nasopharyngeal infection with parainfluenza viruses was seen in two babies with no clinical illness and serotypes 1 and 3 were identified. Cytomegalovirus was isolated in two babies: excretion began after a period of four weeks in both cases and indicated neonatal as opposed to fetal acquisition. Both babies had received multiple blood transfusions. In one baby, infection was associated with a transient but severe neutropenia. Coxsackie B2 infection occurred in two babies within the same week. One of these developed aseptic meningitis but recovered without further sequelae. Rubella infection was diagnosed in one infant with thrombocytopenia and birth asphyxia who died at three weeks of age. Rubella specific IgM antibody was found in the baby's serum, confirming congenital rubella infection.

\section{Discussion}

Few data have been collected on non-bacterial infection in the neonate in this country, partly because investigations of the nature described are not routinely available, and also because they are both time consuming and expensive.

The prevalence of chlamydial infection in this series, 4 of $280(1.4 \%)$, is comparable with that recorded by Schachter in San Francisco, among term infants. ${ }^{2} C$ trachomatis was the most common cause of conjunctivitis in our population, and it is likely that this agent is equally prevalent in other urban centres in this country, where the incidence of sexually transmitted disease is particularly high. Because chlamydial ophthalmia usually occurs towards the end of the first week of life, many babies must develop this condition after discharge from maternity units to the community, where laboratory investigations are not readily available. If untreated, or even if partially treated with inappropriate antibiotics, infected babies may develop pneumonitis or perhaps eye damage.$^{24}$ It follows that chlamydial pneumonitis is not being recognised, especially when it occurs as a primary manifestation of infection. ${ }^{25}$ If the chlamydial isolation rate among term infants in other areas of the country were comparable to that observed in our population, there might be justification for the routine identification of women infected with $C$ trachomatis around the time of delivery. Their newborn infants could then be treated with systemic erythromycin, which has been shown to prevent conjunctivitis in many cases, as well as reducing nasopharyngeal 
infection that is often associated with pneumonitis. ${ }^{26}$ The provision of a routine chlamydial isolation service, as recommended recently for adults, ${ }^{27}$ should be extended to include the care of the newborn.

Ureaplasmas do not seem to be associated with prolonged oxygen dependence; however, their increased incidence in the preterm infant may be related to chorioamnionitis, which occurred most commonly in the mothers of preterm babies. An increased number of babies with apnoea were colonised, even after adjustment for the effect of gestation on apnoea. Although statistical significance was not reached in our study, the findings of Stagno et al ${ }^{10}$ suggested an association with lower respiratory tract infection. Of 104 infants with pneumonitis, $U$ urealyticum was isolated from 8 , and in two of these $U$ urealyticum was the only organism present in the nasopharyngeal aspirates. It is possible that follow up over a longer period would have shown a relation between respiratory tract infections and $U$ urealyticum colonisation in our babies since in vitro studies have shown that these organisms produce fetal trachea epithelial cell damage. ${ }^{28}$ It is not known, however, whether infected infants produce a serological response to these organisms and serological studies to evaluate $U$ urealyticum and $M$ hominis antibodies are currently being undertaken.

As in other studies ${ }^{14}$ the respiratory viral pathogens, respiratory syncytial virus and parainfluenza viruses 1 and 3 , were not associated with lower respiratory tract infection in these preterm infants. Because the two cases of Coxsackie B2 virus infection occurred in the unit within the same week, concern about nosocomial spread was aroused. No further cases were found in the unit, however, and recourse to special control measures were not undertaken. ${ }^{13}$ The use of 'walking' donors for the blood transfusion of the neonate should take into account the risks of cytomegalovirus infection and the debility that this infection can bring to preterm infants. ${ }^{15}$

The rotavirus results were unexpected. While there were too few babies for statistical analysis, rotavirus infection was associated with gastrointestinal disease. There is an urgent need for further virological studies to elucidate the role of this virus in necrotising enterocolitis and bloody diarrhoea.

We gratefully acknowledge the help and advice of Dr Pamela Davies and the generous support of Abbott Laboratories, Queensborough, Kent. We also thank Professor S Darougar, Mr P Earsley (Institute of Ophthalmology), Dr D Taylor Robinson (MRC, Northwick Park Hospital), Dr B Andrews, Mrs M Sillis (Mycoplasma Reference Laboratory, Norwich), Mr P Lister (formerly Virology Department, Royal Postgraduate Medical School), Mr Tim Gluck, and Sister Castle and the nurses of the neonatal intensive care unit. We are grateful to Dr M Silverman and Dr A Whitelaw for allowing us to study their patients; to Professor M E Healey for statistical advice; and to Mrs Lois Gillespie for typing the manuscript.

\section{References}

${ }^{1}$ Harrison HR, English MG, Lee CK, Alexander ER. Chlamydia trachomatis infant pneumonitis. Comparison with matched controls and other infant pneumonitis. $N$ Engl $J$ Med 1978;298:702-8.

2 Schachter J, Holt J, Goodner E, Grossman M, Sweet R, Mills J. Prospective study of chlamydial infection in neonates. Lancet 1979;ii:377-80.

${ }^{3}$ Frommell GT, Rothenberg R, Wang SP, et al. Chlamydial infection of mothers and their infants. J Pediatr 1979;95:28-32.

${ }^{4}$ Hammerschlag MR, Anderka M. Semine DZ, McComb D, McCormack WM. Prospective study of maternal and infantile infection with Chlamydial trachomatis. Pediatrics 1979;64: $142-8$.

${ }^{5}$ Watson PG, Gairdner D. TRIC agent as a cause of neonatal eye sepsis. Br Med J 1968;iii:527-8.

6 Pierce JM, Ward ME, Seal DV. Ophthalmia neonatorum in the 1980s: incidence, aetiology and treatment. Br J Ophthalmol 1982;66:728-31

7 Ross JM, Furr PM, Taylor-Robinson D, Altman DG, Coid CR. The effect of genital mycoplasmas on human fetal growth. Br J Obstet Gynaecol 1981;88:749-55.

${ }^{*}$ Shurin PA, Alpert S, Rossner B, et al. Chorioamnionitis and colonisation of the newborn infant with genital mycoplasmas. $N$ Engl J Med 1975;293:5-8.

9 Klein JO, Buckland D, Finland M. Colonisation of newborn infants by mycoplasmas. $N$ Engl J Med 1969;280:1025-30.

${ }^{10}$ Stagno S, Brasfield DM, Brown MB, et al. Infant pneumonitis associated with cytomegalovirus, chlamydia, pneumocystis and ureaplasma: a prospective study. Pediatrics 1981;68:322-9.

11 Gewitz M, Dinwiddie R, Rees L, et al. Mycoplasma hominis. A cause of neonatal meningitis. Arch Dis Child 1979:54:231-3.

12 Siber GR, Alpert S, Smith AL, Lin JSL, McCormack WM. Neonatal central nervous system infection duc to Mycoplasma hominis. J Pediatr 1977;90:625-7.

13 Nagington J, Wreghitt TG, Gandy G, Roberton NRC, Berry PJ. Fatal echovirus 11 infections in outbreak in special-care baby unit. Lancet 1978;ii:725-8.

14 Hall CB, Kopelman AE, Douglas RG, Geiman JM, Meagher MP. Neonatal respiratory syncytial virus infection. $N$ Engl J Med 1979;300:393-6.

15 Ballard RA, Drew WL, Hufnagle KG, Ricdel PA. Acquired cytomegalovirus infection in preterm infants. Am J Dis Child 1979;133:482-5.

${ }^{16}$ Murphy AM, Albrey MB, Crewe EB. Rotavirus infections of neonates. Lancet 1977;ii:1149-50.

17 Chrystie IL, Totterdell BM, Banatvala JE. Asymptomatic endemic rotavirus infections in the newborn. Lancet 1978;i: $1176-8$.

18 Dearlove J, Latham P, Dearlove B, Pearl K, Thomson A, Lewis IG. Clinical range of neonatal rotavirus gastroenteritis. Br Med J 1983;286:1473-5.

19 Dubowitz LMS, Dubowitz V, Goldberg C. Clinical assessment of gestational age in the newborn infant. J Pediatr 1970;77:1-10.

20 Darougar S, Treharne JD. Cell culture methods for the isolation of $C$ trachomatis-a review. In: P A Mårdh, et al, eds. Chlamydial infections. Amsterdam: Elsevier Biomedical Press. 1982:265-74

21 Ripa KT, Mårdh PA. Cultivation of Chlamydia trachomatis in cycloheximide treated McCoy cells. J Clin Microbiol 1977;6:328-31. 
22 Shepard MC, Lunceford CD. Differential agar medium (A7) for identification of Ureaplasma urealyticum (human T mycoplasmas) in primary culture of clinical material. J Clin Microbiol 1976;3:613-25.

${ }^{23}$ McQuillan J, Gardner PA. Rapid diagnosis of respiratory syncytial virus infection by immunofluorescent antibody techniques. $\mathrm{Br}$ Med $J$ 1968;i:602-5.

${ }^{24}$ Mordhorst $\mathrm{CH}$, Dawson C. Sequelae of neonatal inclusion conjunctivitis and associated disease in parents. Am J Ophthalmol 1971;71:861-7.

${ }^{25}$ Beem MO, Saxon EM. Respiratory tract colonization and a distinctive pneumonia syndrome in infants infected with Chlamydia trachomatis. N Engl J Med 1977;296:306-10.

${ }^{26}$ Patamasucon P, Rettig PJ, Faust KL, Kusmiecz HT, Nelson JD.
Oral v topical erythromycin therapies for chlamydial conjunctivitis. Am J Dis Child 1982;136:817-21.

27 Sexually transmitted diseases. Extract from the annual report of the chief medical officer of the Department of Health and Social Security for the year 1981. Br J Vener Dis 1983;59:206-10.

${ }^{28}$ Quinn PA, Czegledy-Nagy E, Dische R, Sturgess JM. Mycoplasma infection in human fetal trachea. Proceedings of the American Society of Microbiologists 1979; 79th annual meeting. Abstract G25:86.

Correspondence to Dr Peter Rudd, Jenny Lind Children's Department, Norfolk and Norwich Hospital, Brunswick Road, Norwich NR1 3SR.

Received 27 October 1983

British Paediatric Association

Annual meetings

1984 10-14 April York University

1985 16-20 April York University

1986 15-19 April York University

1987 7-11 April York University 